\title{
SOCIALNO-EKONOMSKE IN OKOLJSKE ZNAČILNOSTI REGIONALNEGA RAZVOJA SLOVENIJE PO LETU 2010
}

Izvirni znanstveni članek

COBISS 1.01

DOI: $10.4312 /$ dela.56.53-87

\section{Izvleček}

Zmanjševanje regionalnih razvojnih razlik in uravnotežen razvoj, temelječ na načelih trajnostnega razvoja, sta osrednja cilja regionalne politike v Sloveniji, zato v članku preučujemo uspešnost slovenskih regij pri doseganju teh ciljev na socialno-ekonomskem in okoljskem področju po letu 2010. V ta namen so bili preučeni štirje sintezni kazalniki (bruto domači proizvod na prebivalca, ekološki odtis na prebivalca, indeks razvojne ogroženosti in kazalnik trajnostnega regionalnega razvoja) in 32 posameznih ekonomskih, socialnih in okoljskih kazalnikov, ki so vključeni tudi v izračun kazalnika trajnostnega regionalnega razvoja. Večina ekonomskih in socialnih kazalnikov kaže približevanje strateškim razvojnim ciljem, večina okoljskih pa oddaljevanje od njih.

Ključne besede: razvojne razlike, trajnostni razvoj, statistične regije, Slovenija, kazalniki

*Oddelek za geografijo Filozofske fakultete Univerze v Ljubljani, Aškerčeva cesta 2, SI-1000 Ljubljana e-pošta: katja.vintarmally@ff.uni-lj.si 


\section{UVOD}

Dolgoletnim prizadevanjem slovenske regionalne politike za zmanjševanje razvojnih razlik v državi se v zadnjih dveh desetletjih čedalje bolj izrazito pridružuje tudi podpora bolj trajnostnim razvojnim vzorcem. Skladnejši regionalni razvoj se v Sloveniji spodbuja tako z nacionalno zakonodajo in ukrepi (Zakon o spodbujanju skladnega ..., 2011) kot tudi s kohezijsko politiko Evropske unije, ki krepi ekonomsko, socialno in teritorialno kohezijo, za prihajajoče programsko obdobje pa napoveduje še posebej veliko podporo zelenemu in digitalnemu prehodu (Cohesion policy 2021-2027, 2021). Slovenija in njene regije niso zavezane $\mathrm{k}$ trajnostnemu razvoju le prek regionalne politike, temveč tudi s številnimi drugimi politikami in dokumenti, kot sta denimo krovni evropska in nacionalna strategija trajnostnega razvoja (Renewed EU sustainable development strategy, 2006; Strategija razvoja Slovenije 2030, 2017) ter Evropski zeleni dogovor (The European green deal, 2019), ki vsebinsko sledijo zlasti Agendi 2030 (Transforming our world ..., 2015) oziroma njeni predhodnici Agendi 21 (1992).

Analiza v članku se nanaša na dvanajst slovenskih statističnih regij na ravni NUTS3 (v nadaljevanju: regije), ki v Sloveniji nimajo statusa administrativnih enot, so pa vseeno odgovorne za načrtovanje regionalne politike in izvajanje nalog regionalnega razvoja (Zakon o spodbujanju skladnega ..., 2011) kot tako imenovane razvojne regije. V ospredju zanimanja preučitve so bile značilnosti regionalnega razvoja Slovenije in njihovo vrednotenje $\mathrm{v}$ luči približevanja ciljem trajnostnega kot tudi skladnejšega regionalnega razvoja na socialno-ekonomskem in okoljskem področju. $\mathrm{V}$ ta namen smo preučili štiri sintezne kazalnike (bruto domači proizvod na prebivalca, ekološki odtis na prebivalca, indeks razvojne ogroženosti in kazalnik trajnostnega regionalnega razvoja) ter podrobneje še vseh 32 kazalnikov, vključenih v izračun kazalnika trajnostnega regionalnega razvoja. Raziskava je na podlagi analize stanja in trendov po letu 2010 skušala odgovoriti na vprašanje, na katerih področjih se regije približujejo ciljem bolj skladnega in trajnostnega razvoja oziroma na katerih področjih izkazujejo največji zaostanek.

\section{TEORETIČNA IZHODIŠČA IN METODE}

Za regionalno politiko v Sloveniji je ključnega pomena Zakon o spodbujanju skladnega regionalnega razvoja (2011), ki opredeljuje regionalno politiko kot strukturno politiko za doseganje skladnega regionalnega razvoja, pri čemer naj bi se vse odločitve sprejemale v skladu $\mathrm{z}$ načelom trajnostnega razvoja. Zakon določa, da so temeljni strateški in programski dokumenti na ravni regij regionalni razvojni programi, ki se pripravljajo za večletna programska obdobja, vlada pa določa cilje in usmeritve zanje prek dveh strategij: strategije razvoja Slovenije in strategije prostorskega razvoja (Zakon o spodbujanju skladnega ..., 2011). Medtem ko je bila zadnja Strategija razvoja Slovenije 
za obdobje do leta 2030 sprejeta v letu 2017, je Strategija prostorskega razvoja do leta 2050 še vedno v postopkih priprave (Priprava Strategije ..., 2021). Strategija razvoja Slovenije sicer skladnejšega regionalnega razvoja ne izpostavlja niti med strateškimi usmeritvami niti med cilji, a kljub temu na več mestih poudari pomen enakomernejšega razvoja države in njenih regij. Prav tako je osrednja ambicija strategije doseganje kakovostnega življenja za vse prebivalce, kar se nanaša na vse regije v državi in kar naj bi bilo možno doseči »z uravnoteženim gospodarskim, družbenim in okoljskim razvojem, ki upošteva omejitve in zmožnosti planeta ter ustvarja pogoje in priložnosti za sedanje in prihodnje rodove (Strategija razvoja Slovenije, 2017, str. 17). Ker se v Sloveniji ne pripravlja več samostojne državne strategije regionalnega razvoja (Pečar, 2020 b), se lahko regije pri pripravi regionalnih razvojnih programov za programsko obdobje 2021-2027 opirajo le na navedeni strategiji ter usmeritve resornega ministrstva (Operativni načrt ..., 2019) in vlade (Cilji, usmeritve in instrumenti ..., 2019). Do leta 2030 morajo regionalni razvojni programi upoštevati štiri osnovne razvojne cilje (Cilji, usmeritve in instrumenti ..., 2019, str. 21):

- „ „dvig kakovosti življenja v vseh regijah z uravnoteženim gospodarskim, družbenim in okoljskim razvojem, ki temelji na načelih trajnostnega razvoja,

- razvojno dohitevanje evropskih regij,

- zmanjšanje regionalnih razvojnih razlik,

- uresničevanje razvojnih potencialov in izkoriščanje globalnih priložnosti z mednarodnim medregionalnim povezovanjem in sodelovanjem «.

V Sloveniji tako obstajajo podlage za spodbujanje skladnejšega regionalnega razvoja, ki naj bi ob dvigu kakovosti življenja v vseh regijah stremel k zmanjševanju regionalnih razlik in doseganju ciljev trajnostnega razvoja na vseh temeljnih področjih (ekonomskem, socialnem in okoljskem). Pogreša pa se celovit in enoten način spremljanja učinkov regionalne politike (Pečar, 2020b), saj zakon določa le način razvrščanja regij po stopnji razvitosti s tako imenovanim indeksom razvojne ogroženosti (Zakon o spodbujanju skladnega ..., 2011), vladno gradivo za programsko obdobje 2021-2027 (Cilji, usmeritve in instrumenti ..., 2019) pa za spremljanje posameznih ciljev predlaga več kazalnikov, a zanje ne določa ciljnih vrednosti. Kljub temu lahko $\mathrm{v}$ prihodnje na račun opredelitve teh kazalnikov pričakujemo določen napredek pri spremljanju učinkov regionalne politike v primerjavi s predhodnimi obdobji.

Za preučitev socialno-ekonomskih in okoljskih značilnosti regionalnega razvoja slovenskih regij po letu 2010 smo uporabili štiri ključne kazalnike, ki se lahko uporabljajo na ravni regij in so izrazito sinteznega značaja: bruto domači proizvod (BDP) na prebivalca, indeks razvojne ogroženosti (IRO), ekološki odtis (EO) na prebivalca in kazalnik trajnostnega regionalnega razvoja (KTRR). Izbrana so bila zadnja leta oziroma obdobja, za katera so na voljo razpoložljivi podatki in izračuni navedenih kazalnikov. V nadaljevanju smo bolj podrobno preučili trende v zadnjem desetletju prek KTRR, ki v svoj izračun vključuje kar 32 kazalnikov za ekonomske, socialne in 
okoljske vidike trajnostnega razvoja, med njimi tudi BDP na prebivalca in posamezne kazalnike, ki jih upošteva tudi IRO.

BDP na prebivalca je že desetletja vodilni kazalnik gospodarske blaginje in gospodarske rasti, neupravičeno pa se ga še vedno uporablja tudi za ponazarjanje socialno-ekonomskega napredka in blaginje (Kalimeris in sod., 2020; van den Bergh, 2009; Ward in sod., 2016). Kljub mnogim metodološkim pomanjkljivostim smo ga izbrali za ključni ekonomski kazalnik za potrebe osnovne primerjave regij, več drugih kazalnikov z ekonomskega področja namreč vključujeta tako KTRR kot tudi IRO. BDP na prebivalca je Strategija razvoja Slovenije (2017) določila za enega izmed šestih ključnih kazalnikov za spremljanje uspešnosti strategije, po kateri ima država do leta 2030 cilj doseči povprečje BDP na prebivalca v Evropski uniji (v izhodiščnem letu 2015 je dosegala $83 \%$ povprečnega BDP na prebivalca v Evropski uniji).

Na drugi strani smo za vodilni okoljski kazalnik izbrali EO na prebivalca, ki izračunava obseg bioproduktivnih kopnih in vodnih površin, potrebnih za proizvodnjo virov, ki jih porablja povprečni prebivalec določenega območja, in za absorpcijo proizvedenih odpadkov. EO se izraža v globalnih hektarjih (gha) kot hektarjih s povprečno svetovno produktivnostjo (Global Footprint Network, 2019). Čeprav tudi ta kazalnik izkazuje mnoge metodološke omejitve (Galli in sod., 2016), je izjemno uporaben za ozaveščanje in komuniciranje problematike pretirane potrošnje (O'Neill in sod., 2018; Wiedmann, Barrett, 2010), zlasti še v luči preseganja nosilnih zmogljivosti okolja. Sočasno se namreč izračunava tudi biokapaciteta območij oziroma zmogljivost biosfere, da zagotavlja in obnavlja naravne vire in storitve (Global Footprint Network, 2019). V Strategiji razvoja Slovenije (2017) je bil EO na prebivalca izbran za kazalnik pri vrednotenju doseganja cilja trajnostnega upravljanja naravnih virov. Strategija je za cilj zastavila, da se od izhodiščnega leta 2013 do leta $2030 \mathrm{EO}$ na prebivalca Slovenije zniža s 4,7 gha na prebivalca na 3,8 gha na prebivalca. Po zadnjih izračunih Global Footprint Networka (2021) je leta 2017 EO na prebivalca v Sloveniji znašal 4,9 gha in je tako za 2,7 gha presegal razpoložljivo biokapaciteto na prebivalca v državi. V analizi smo uporabili izračune ekološkega odtisa in biokapacitete slovenskih regij za leto 2016 iz študije, ki so jo Lin in sodelavci (2020) pripravili kot izhodišče za oblikovanje regionalnih razvojnih programov, za katere je država določila, da se ekološki odtis uporablja kot vodilni kazalnik na področju okolja (Cilji, usmeritve in instrumenti ..., 2019).

Tretji izbrani kazalnik je IRO, katerega izračunavanje je predpisano v Zakonu o spodbujanju skladnega regionalnega razvoja (2011) in pripadajočem pravilniku za posamezno programsko obdobje (Pravilnik o razvrstitvi ..., 2021). V skladu s tema dokumentoma IRO vključuje 14 kazalnikov: BDP na prebivalca, bruto dodana vrednost na zaposlenega, bruto investicije $\mathrm{v}$ osnovna sredstva $\mathrm{v} \% \mathrm{BDP}$, stopnja registrirane brezposelnosti mladih (15-29 let), stopnja delovne aktivnosti (20-64 let), delež prebivalstva s terciarno izobrazbo (25-64 let), bruto domači izdatki za raziskovalno in razvojno dejavnost $\mathrm{v} \% \mathrm{BDP}$, delež prečiščene odpadne vode s sekundarnim in terciarnim čiščenjem, delež varovanih območij, ocenjena škoda zaradi elementarnih 
nesreč v \% BDP, stopnja registrirane brezposelnosti, indeks staranja prebivalstva, razpoložljivi dohodek na prebivalca in gostota poselitve. Zadnji izračuni IRO so na voljo za leto 2019 (Pečar, 2020a) in prav na njihovi podlagi je bilo opravljeno razvrščanje regij po stopnji razvitosti za programsko obdobje 2021-2027.

Že pred uvedbo IRO v spremljanje učinkov regionalne politike v Sloveniji je bil razvit KTRR, ki je bil izračunan za več zaporednih obdobij od druge polovice 90. let 20. stoletja dalje z osnovnim namenom spremljanja oddaljevanja oziroma približevanja slovenskih regij ciljem trajnostnega razvoja (Vintar, 2003; Vintar Mally, 2009; 2018; 2021). Tudi KTRR je doživel nekaj metodoloških sprememb zaradi (ne)razpoložljivosti podatkov ali sprememb v zbiranju uporabljenih podatkov. Za obdobje 2015-2019 je bil KTRR izračunan na podlagi naslednjih 32 kazalnikov (Vintar Mally, 2021):

- ekonomski kazalniki: BDP na prebivalca, bruto dodana vrednost na prebivalca, investicije v osnovna sredstva na prebivalca, povprečni izdatki za raziskovanje in razvoj v \% BDP, razpoložljivi dohodek na prebivalca, delež zaposlenih v storitvenih dejavnostih;

- socialni kazalniki: delež brezposelnih s I. in II. stopnjo izobrazbe, delež žensk med brezposelnimi, gostota poselitve, indeks rasti prebivalstva, indeks staranja, povprečna starost umrlega, stopnja tveganja socialne izključenosti, stanovanjske površine na prebivalca, stopnja registrirane brezposelnosti, število študentov na 1000 prebivalcev, delež gospodinjstev z uporabo osebnih računalnikov, delež višje- in visokošolsko izobraženih;

- okoljski kazalniki: delež ekološko obdelanih kmetijskih zemljišč, gozdnate površine na prebivalca, indeks rasti cestnega tovornega prometa, intenzivno obdelana kmetijska zemljišča na prebivalca, delež gospodinjstev v onesnaženem okolju, komunalni odpadki na prebivalca, delež Natura 2000 območij, poraba vode na prebivalca, investicije v varstvo okolja v \% BDP, delež pozidanih površin, delež prečiščene odpadne vode, delež stanovanj z daljinskim ogrevanjem, stopnja motorizacije, živinorejska gostota.

Ugotovimo lahko, da IRO in KTRR vključujeta šest enakih socialno-ekonomskih kazalnikov (tj. BDP na prebivalca, delež prebivalstva s terciarno izobrazbo (25-64 let), stopnja registrirane brezposelnosti, indeks staranja prebivalstva, razpoložljivi dohodek na prebivalca in gostota poselitve), vendar se pri oblikovanju sestavljenega kazalnika uporabljata povsem različni metodi. Za KTRR je uporabljen izračun standardnega odklona pri vsakem posameznem kazalniku, kar je osnova za razvrščanje regij v štiri razrede glede na oddaljenost vrednosti od povprečja regij in želene smeri gibanja kazalnika $\mathrm{z}$ vidika trajnostnega razvoja. Ocena $(++,+,-$ ali --$)$, ki je regiji dodeljena pri vsakem kazalniku, je izhodišče za izračunavanje povprečne ocene regije na vsakem izmed treh razvojnih področij - ekonomskem, socialnem in okoljskem in povprečne vrednosti vseh treh področij, ki je vrednost KTRR (Vintar Mally, 2021). Pri IRO se izračunavajo standardizirane vrednosti za vsak kazalnik na lestvici od 0 
do 1 , in sicer na podlagi uporabe minimalnih in maksimalnih vrednosti, ki se pojavljajo v regijah pri posameznih kazalnikih. Medtem ko ima pri IRO vsak izmed štirinajstih kazalnikov enako težo oziroma vpliv na končni rezultat (Pečar, 2018), imajo pri KTRR enako težo le kazalniki znotraj posameznega področja (ekonomskega, socialnega in okoljskega), na končno višino KTRR regije pa ima enak vpliv vsako izmed treh področij. Sklenemo lahko, da imajo okoljski kazalniki pri KTRR tretjinski vpliv na končno vrednost sestavljenega kazalnika, pri IRO pa največ petino vpliva (tj. trije kazalniki od skupno 14, če ob kazalnikih o deležu prečiščene odpadne vode in deležu varovanih območij za okoljski kazalnik štejemo tudi ocenjeno škodo zaradi elementarnih nesreč).

\section{REZULTATI IN RAZPRAVA}

Z vidika bolj skladnega in trajnostnega razvoja je zaželeno zviševanje materialne blaginje in $\mathrm{z}$ njo tudi rast bruto domačega proizvoda. V letu 2019 je bil najnižji BDP na prebivalca v Zasavski (12.287 EUR na prebivalca) in najvišji v Osrednjeslovenski regiji (32.620 EUR na prebivalca), razmerje med obema regijama pa je po tem kazalniku znašalo $1: 2,7$. Navedeno kaže na še vedno velike razlike med regijami, ki so se v obdobju 2010-2019 povečale (leta 2010 je bilo razmerje $1: 2,4$ ) (SURS, 2021). V trojici gospodarsko najšibkejših regij so bile Zasavska, Pomurska in Primorsko-notranjska regija, med najmočnejšimi pa ob Osrednjeslovenski regiji še Jugovzhodna Slovenija in Obalno-kraška regija (preglednica 1). V zgornjo polovico lestvice so se tako uvrstile vse statistične regije, ki na NUTS-2 ravni tvorijo kohezijsko regijo Zahodna Slovenija (tj. Osrednjeslovenska, Obalno-kraška, Gorenjska in Goriška regija), dodatno pa tudi Jugovzhodna Slovenija in Savinjska regija iz kohezijske regije Vzhodna Slovenija (slika 1). Podobne rezultate kažejo tudi izračuni IRO, po katerih se rangi pri devetih regijah povsem ujemajo oziroma razlikujejo za največ eno mesto s tistimi pri BDP na prebivalca, medtem ko se je Podravska regija po IRO uvrstila za dve mesti slabše kot po BDP na prebivalca, Zasavska in Gorenjska pa za tri mesta višje. Po izračunih IRO za leto 2019 se je za najbolj razvito oziroma najmanj razvojno ogroženo izkazala Osrednjeslovenska regija (indeks 49,6), za najmanj razvite pa Pomurska (172,5), Primorsko-notranjska $(138,3)$ in Podravska regija $(133,4)$. Primerjava rezultatov IRO za leti 2014 in 2019 je pokazala, da so se v večini regij kazalniki, ki so vključeni v IRO, izboljšali, vendar se je zaostanek regij za Osrednjeslovensko še povečal in s tem tudi razlika med najbolje in najslabše uvrščenima regijama (Pečar, 2020a). Izračuni BDP in IRO torej kažejo napredek regij, a tudi povečanje medregionalnih razlik. 
Preglednica 1: Primeriava rezultatov slovenskih statičnih regii po izbranih razvojnih kazalnikih.

\begin{tabular}{|l|c|c|c|c|c|}
\hline & $\begin{array}{c}\text { BDP na } \\
\text { prebivalca } \\
(\mathbf{(}), \mathbf{2 0 1 9}\end{array}$ & $\begin{array}{c}\text { Ekološki } \\
\text { odtis na } \\
\text { prebivalca } \\
\text { (gha), 2016 }\end{array}$ & $\begin{array}{c}\text { Biokapa- } \\
\text { citeta na } \\
\text { prebivalca } \\
\text { (gha), 2016 }\end{array}$ & $\begin{array}{c}\text { Indeks } \\
\text { razvojne } \\
\text { ogrože- } \\
\text { nosti, } \\
\mathbf{2 0 1 9}\end{array}$ & $\begin{array}{c}\text { Kazalnik } \\
\text { trajnostnega } \\
\text { regionalne- } \\
\text { ga razvoja, } \\
\mathbf{2 0 1 5 - 2 0 1 9}\end{array}$ \\
\hline Osrednjeslovenska & $\mathbf{3 2 . 6 2 0}$ & 5,28 & 1,11 & $\mathbf{4 9 , 6}$ & $\mathbf{0 , 7 3}$ \\
\hline Jugovzhodna Slovenija & $\mathbf{2 3 . 0 9 6}$ & 5,27 & $\mathbf{5 , 3 8}$ & $\mathbf{9 3 , 0}$ & $\mathbf{0 , 4 8}$ \\
\hline Gorenjska & 20.790 & 5,29 & 2,69 & $\mathbf{8 5 , 3}$ & $\mathbf{0 , 4 8}$ \\
\hline Goriška & 20.707 & 5,29 & $\mathbf{5 , 3 0}$ & 117,1 & 0,44 \\
\hline Obalno-kraška & $\mathbf{2 2 . 8 9 4}$ & 5,26 & 2,54 & 103,2 & 0,18 \\
\hline Primorsko-notranjska & 16.154 & 5,25 & $\mathbf{8 , 0 2}$ & 138,3 & 0,17 \\
\hline Koroška & 18.694 & 5,40 & 3,98 & 127,7 & $-0,09$ \\
\hline Savinjska & 20.954 & 5,19 & 2,15 & 109,3 & $-0,31$ \\
\hline Posavska & 19.456 & 5,19 & 3,03 & 121,8 & $-0,36$ \\
\hline Zasavska & 12.287 & $\mathbf{5 , 1 6}$ & 2,18 & 132,3 & $-0,45$ \\
\hline Podravska & 18.887 & $\mathbf{5 , 1 8}$ & 1,46 & 133,4 & $-0,59$ \\
\hline Pomurska & 15.705 & $\mathbf{5 , 1 5}$ & 2,46 & 172,5 & $-0,82$ \\
\hline Slovenija & 23.165 & 5,24 & 2,50 & $/$ & $/$ \\
\hline
\end{tabular}

Viri: Lin in sod., 2020; Pečar, 2020a; SURS, 2021; Vintar Mally, 2021.

Opomba: s krepko pisavo so zapisane najugodnejše vrednosti posameznih kazalnikov.

V primerjavi z rezultati predhodno predstavljenih, pretežno socialno-ekonomskih kazalnikov, se regije razvrščajo povsem drugače po EO na prebivalca kot sinteznem kazalniku pritiskov na okolje. Pri tem kazalniku so za trajnostni razvoj slovenskih regij ugodnejše nižje vrednosti, zato so najvišje uvrščene regije z najnižjimi pritiski na okolje. Leta 2016 je imela najnižji EO na prebivalca Pomurska regija s 5,15 gha na prebivalca, največjega pa Koroška regija s 5,40 gha na prebivalca, kar je v tej regiji posledica nadpovprečno visokega odtisa prometa in gospodinjstev (Lin in sod., 2020). Slovenija večkratno presega razpoložljivo globalno biokapaciteto na prebivalca, ki znaša 1,6 gha, prav tako pa tudi biokapaciteto svojega ozemlja. Razvojno neugodna je tudi ugotovitev, da se je ekološki odtis države od začetka 90. let 20. stoletja večinoma povečeval, $\mathrm{z}$ izjemo večjega upada, ki je sledil svetovni finančno-gospodarski krizi pred dobrim desetletjem (Global Footprint Network, 2021). Primerjava biokapacitete in EO na prebivalca (preglednica 1) za večino regij pokaže ekološki deficit, saj EO prebivalcev regije bistveno presega biokapaciteto njenega ozemlja. Po višini ekološkega deficita najbolj izstopata Osrednjeslovenska (4,17 gha na prebivalca) in Podravska regija (3,72 gha na 
prebivalca). Le tri regije z največjo biokapaciteto - Primorsko-notranjska, Jugovzhodna Slovenija in Goriška regija - izkazujejo presežek biokapacitete nad ekološkim odtisom, kar je predvsem posledica najbolj obsežnih gozdnatih površin v razmerju do števila prebivalcev. Ekološki deficit kaže, da je razvojni vzorec v državi izrazito netrajnosten in da se v večini regij socialno-ekonomski razvoj odvija na račun izčrpavanja globalnih ali lokalnih okoljskih virov in onesnaževanja okolja. Glede na način izračunavanja ekološkega odtisa so ti učinki porazdeljeni na vsa območja, s katerih se prebivalci regij oskrbujejo $\mathrm{z}$ blagom in storitvami kot tudi viri surovin in energije. Razlike v višini EO na prebivalca so med regijami bistveno manjše od razlik v bruto domačem proizvodu, na podlagi česar bi lahko sklepali, da se v gospodarsko uspešnejših regijah ustvarja višja dodana vrednost s primerjalno manjšimi pritiski na okolje. Največje razlike v rangih po BDP na prebivalca in EO na prebivalca so v Pomurski in Zasavski regiji, ki imata najnižji vrednosti EO na prebivalca in hkrati tudi najnižji vrednosti BDP na prebivalca. $V$ povprečju se rangi regij po obeh kazalnikih razlikujejo za pet mest, nadpovprečno še pri Osrednjeslovenski regiji (prva po BDP na prebivalca in deveti najvišji EO na prebivalca) in Jugovzhodni Sloveniji (druga po BDP na prebivalca in osmi najvišji EO na prebivalca). Podobno velike so tudi razlike v rangih EO na prebivalca in IRO.

Slika 1: Rangi slovenskih statističnih regii po izbranih razvojnih kazalnikih, 2015-2019.

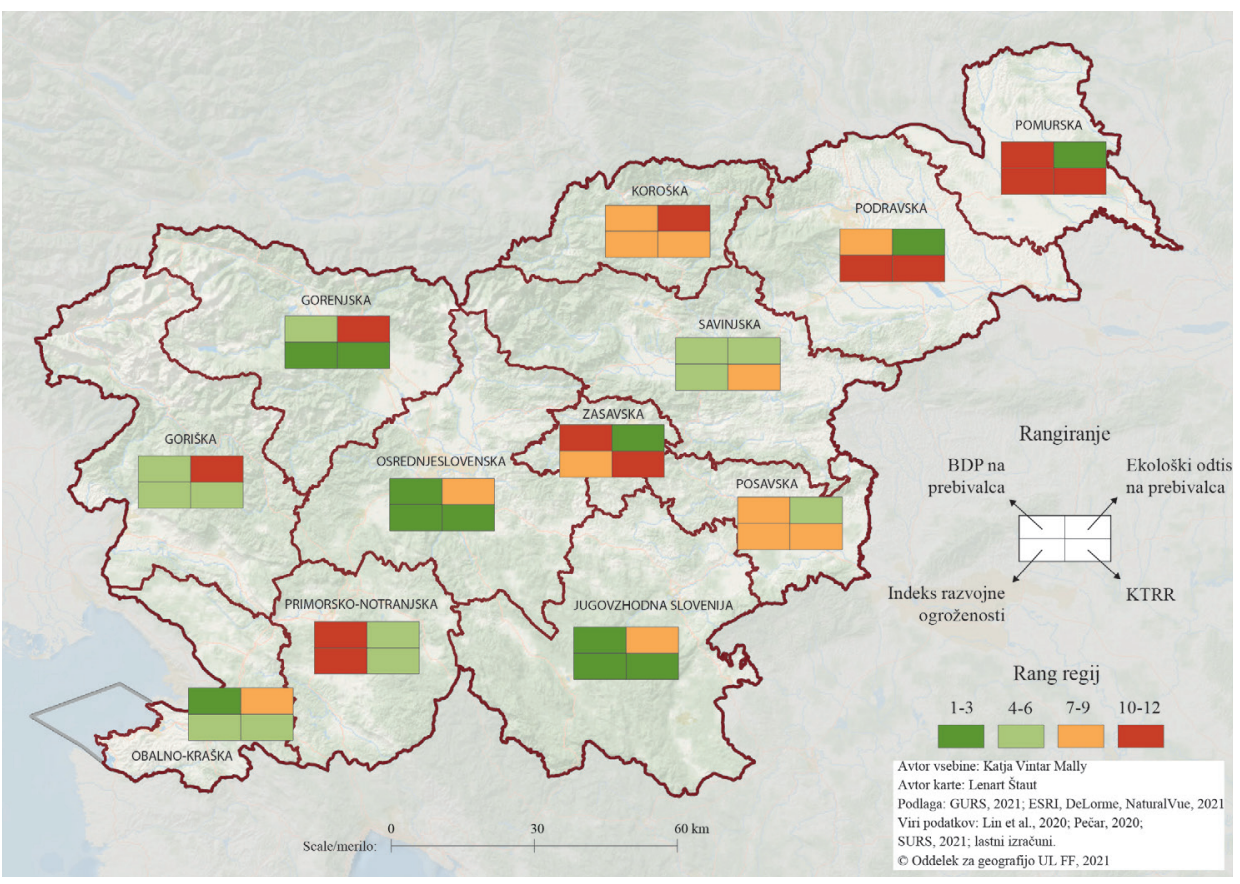


KTRR enakovredno vključuje $\mathrm{v}$ izračun tako kazalnike $\mathrm{z}$ ekonomskega, socialnega kot tudi okoljskega področja, zato so že v izhodišču pričakovani drugačni rezultati kot pri predhodnih kazalnikih. Razvrščanje regij po KTRR je primerjalno bližje razvrščanju po višini IRO kot pa po izključno ekonomskem (BDP na prebivalca) ali okoljskem kazalniku (EO na prebivalca). Poleg izbire vključenih kazalnikov na razlike med KTRR in IRO najbolj vpliva dejstvo, da imajo pri KTRR socialni in ekonomski kazalniki manjšo težo oziroma enako kot okoljski (tj. vsako področje ima tretjino vpliva). Najvišje uvrščene po KTRR so regije v zahodnem delu države: Osrednjeslovenska, Gorenjska, Jugovzhodna Slovenija, Goriška, Obalno-kraška in Primorsko-notranjska regija. Rangi IRO in KTRR so se v osmih regijah razlikovali za največ eno mesto, medtem ko je bila Goriška regija po KTRR uvrščena za dve mesti višje (na četrto mesto po KTRR) in Posavska regija za dve mesti nižje (na deveto mesto po KTRR). Najbolj sta odstopali Savinjska regija, ki se je po KTRR uvrstila za tri mesta nižje (na osmo mesto) kot po IRO, Primorsko-notranjska pa kar za pet mest višje (na šesto mesto) kot po IRO.

Za izračun KTRR je bilo na ekonomskem področju upoštevanih šest kazalnikov, na socialnem področju dvanajst in na okoljskem področju štirinajst kazalnikov. Tudi primerjava rezultatov regij po področjih KTRR (preglednica 2) pokaže na velik razkorak $\mathrm{v}$ rangih regij na socialnem in ekonomskem področju v primerjavi z rangi regij na okoljskem področju (slika 2). Medtem ko se regije na zahodu države, zlasti še tiste iz kohezijske regije Zahodna Slovenija, uvrščajo po ekonomskih in socialnih kazalnikih na vrh lestvice, rezultati pri okoljskih kazalnikih bistveno odstopajo od tega vzorca. Najbolj izrazit primer je Osrednjeslovenska regija, ki zaseda prvo mesto na ekonomskem in drugo na socialnem področju, na okoljskem področju pa se je uvrstila na zadnje mesto. Znaten razkorak med ugodnostjo socialno-ekonomskega in okoljskega področja za dolgoročni trajnostni razvoj je tudi v Obalno-kraški in Gorenjski regiji. Na drugi strani pa sta na okoljskem področju zasedli prvi dve mesti Zasavska in Koroška regija, ki sta med socialno-ekonomsko šibkejšimi. Čeprav so v obeh regijah prisotna območja starih okoljskih bremen, pa po kazalnikih pritiskov na okolje (npr. poljedelstva, prometa, pozidanih površin, rabe vode in nastajanja odpadkov) in kazalnikih odzivov (npr. ekološko kmetijstvo, daljinsko ogrevanje) kažeta nadpovprečno ugodno stanje in trende. 
Preglednica 2: Povprečne ocene slovenskih statističnih regii na glavnih razvojnih področjih in kazalnik trajnostnega regionalnega razvoja, 2015-2019.

\begin{tabular}{|c|c|c|c|c|c|}
\hline & \multirow[t]{2}{*}{$\begin{array}{c}\text { Ekonomski } \\
\text { kazalniki }\end{array}$} & \multirow[t]{2}{*}{$\begin{array}{l}\text { Socialni } \\
\text { kazalniki }\end{array}$} & \multirow[t]{2}{*}{$\begin{array}{l}\text { Okoljski } \\
\text { kazalniki }\end{array}$} & \multicolumn{2}{|c|}{$\begin{array}{l}\text { Kazalnik trajnostnega } \\
\text { regionalnega razvoja }\end{array}$} \\
\hline & & & & vrednost & rang \\
\hline Osrednjeslovenska & 1,83 & 1,00 & $-0,64$ & 0,73 & 1 \\
\hline Jugovzhodna Slovenija & 0,83 & 0,25 & 0,36 & 0,48 & $2-3$ \\
\hline Gorenjska & 0,33 & 1,25 & $-0,14$ & 0,48 & $2-3$ \\
\hline Goriška & 0,33 & 0,92 & 0,07 & 0,44 & 4 \\
\hline Obalno-kraška & 0,50 & 0,33 & $-0,29$ & 0,18 & 5 \\
\hline Primorsko-notranjska & $-0,67$ & 0,67 & 0,50 & 0,17 & 6 \\
\hline Koroška & $-0,67$ & $-0,17$ & 0,57 & $-0,09$ & 7 \\
\hline Savinjska & 0,00 & $-0,42$ & $-0,50$ & $-0,31$ & 8 \\
\hline Posavska & $-0,67$ & $-0,42$ & 0,00 & $-0,36$ & 9 \\
\hline Zasavska & $-1,17$ & $-0,83$ & 0,64 & $-0,45$ & 10 \\
\hline Podravska & $-0,83$ & $-0,50$ & $-0,43$ & $-0,59$ & 11 \\
\hline Pomurska & $-1,17$ & $-1,00$ & $-0,29$ & $-0,82$ & 12 \\
\hline
\end{tabular}

Vir: Vintar Mally, 2021.

Primerjava izračunov KTRR za obdobje 2015-2019 s predhodnimi obdobji je pokazala, da se je najbolj spreminjal prav položaj regij na okoljskem področju, medtem ko so razlike na socialnem in ekonomskem področju bolj zakoreninjene oziroma so razmerja manj spremenljiva (Vintar Mally, 2018; 2021). Prav tako se je v obdobju 2015-2019 ponovno potrdilo, da so bile razlike med regijami najmanjše na okoljskem področju, kjer je znašala razlika med najboljše ocenjeno Zasavsko regijo in najslabše ocenjeno Osrednjeslovensko regijo 1,28. Na ekonomskem področju je znašala razlika med najbolje in najslabše uvrščeno regijo 3,0, na socialnem področju pa 2,25. Z vidika skladnejšega razvoja slovenskih regij je spodbudna predvsem ugotovitev, da so se pri ekonomskih kazalnikih KTRR nekoliko zmanjšale razlike, medtem ko so na socialnem področju ostale nespremenjene. Zelo malo se je v zadnjem desetletju spremenil tudi vrstni red regij po višini KTRR (preglednica 3), saj so le tri regije spremenile mesto na lestvici kot posledica dejstva, da sta Jugovzhodna Slovenija in Gorenjska v zadnjem obdobju prehiteli Goriško regijo, ki je bila predhodno na drugem mestu. 
Slika 2: Rangi slovenskih statističnih regii na glavnih razvojnih področih in pri kazalniku trajnostnega regionalnega razvoja, 2015-2019.

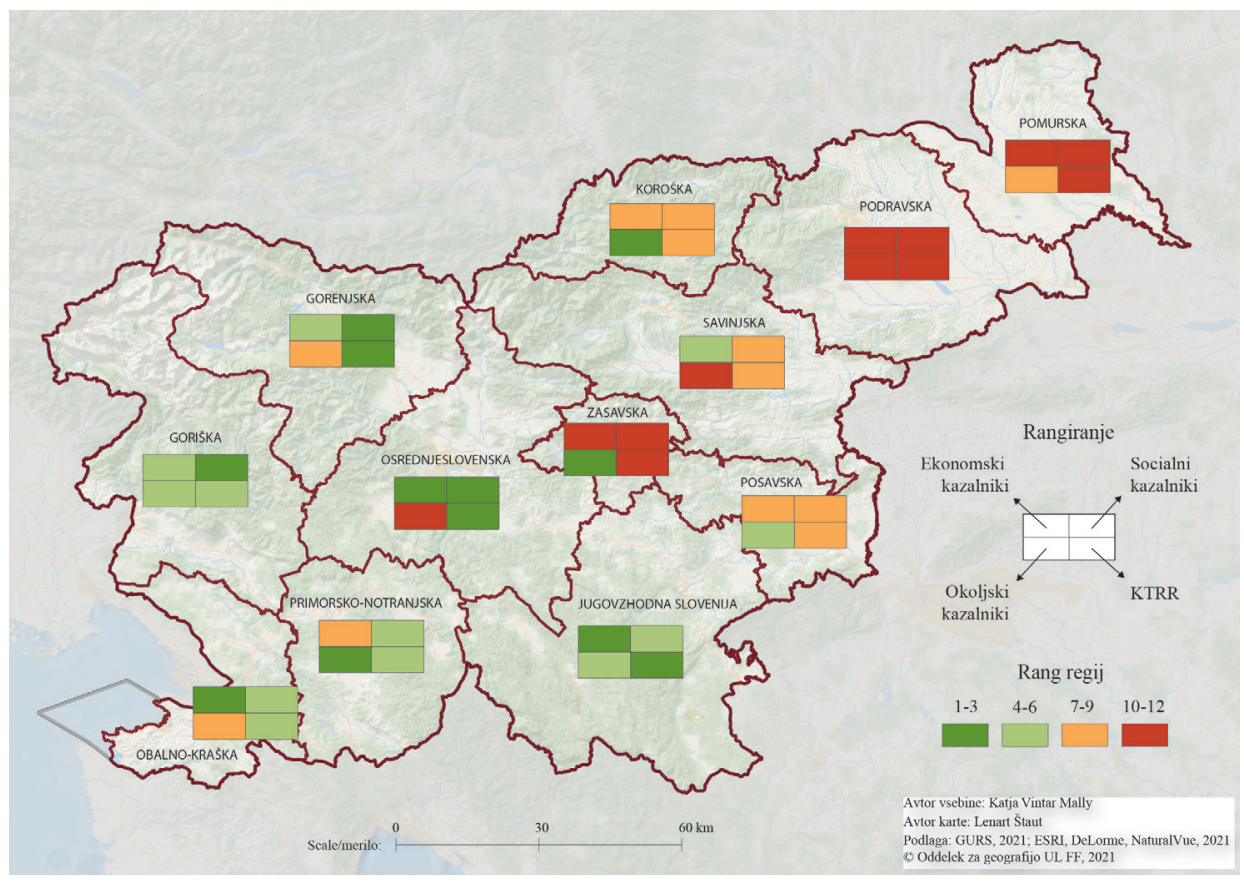


Preglednica 3: Primerjava kazalnika trajnostnega regionalnega razvoja v obdobjih 20102014 in 2015-2019.

\begin{tabular}{|l|c|c|c|c|}
\hline \multirow{2}{*}{} & \multicolumn{2}{|c|}{ 2010-2014 } & \multicolumn{2}{c|}{ 2015-2019 } \\
\cline { 2 - 5 } & vrednost & rang & vrednost & rang \\
\hline Osrednjeslovenska & 0,85 & 1 & 0,73 & 1 \\
\hline Jugovzhodna Slovenija & 0,44 & 3 & 0,48 & $2-3$ \\
\hline Gorenjska & 0,32 & 4 & 0,48 & $2-3$ \\
\hline Goriška & 0,45 & 2 & 0,44 & 4 \\
\hline Obalno-kraška & 0,30 & 5 & 0,18 & 5 \\
\hline Primorsko-notranjska & 0,27 & 6 & 0,17 & 6 \\
\hline Koroška & $-0,14$ & 7 & $-0,09$ & 7 \\
\hline Savinjska & $-0,17$ & 8 & $-0,31$ & 8 \\
\hline Posavska & $-0,54$ & 9 & $-0,36$ & 9 \\
\hline Zasavska & $-0,70$ & 10 & $-0,45$ & 10 \\
\hline Podravska & $-0,76$ & 11 & $-0,59$ & 11 \\
\hline Pomurska & $-0,77$ & 12 & $-0,82$ & 12 \\
\hline
\end{tabular}

Vir: Vintar Mally, 2018; 2021.

Podrobnejša preučitev rezultatov za vseh 32 kazalnikov, ki so bili vključeni v izračun KTRR v obdobjih 2010-2014 in 2015-2019, nudi še boljši vpogled v socialno-ekonomske in okoljske značilnosti regionalnega razvoja po letu 2010 in v ugodnost teh trendov za trajnostni razvoj države. Na socialno-ekonomskem področju je prišlo do izboljšanja pri večini analiziranih kazalnikov, saj so regije napredovale v smeri gospodarskih ciljev trajnostnega razvoja, zmanjšala se je brezposelnost (na splošno in pri različnih skupinah prebivalcev) in izboljšala izobrazba prebivalcev, ki v povprečju živijo dlje in v boljših stanovanjskih razmerah. Med neugodnimi socialno-ekonomskimi trendi velja izpostaviti povprečno zmanjšanje izdatkov za raziskovanje in razvoj, staranje prebivalstva, upadanje prebivalstvene rasti v nekaterih regijah in zgoščevanje prebivalstva $\mathrm{v}$ drugih. Za razliko od socialno-ekonomskih kazalnikov je primerjava trendov in stanja pri okoljskih kazalnikih pokazala večinoma oddaljevanje od ciljev trajnostnega razvoja. Bolj trajnostne prakse smo tako v povprečju zasledili na področju ogrevanja gospodinjstev s širjenjem daljinskega ogrevanja in v kmetijstvu s širjenjem ekološkega kmetijstva ter zmanjševanjem pritiskov na intenzivno obdelanih kmetijskih zemljiščih in s strani živinoreje. Neugodni so zlasti trendi povečevanja rabe vode, naraščanja količin komunalnih odpadkov, širjenja pozidanih površin, rasti cestnega tovornega prometa, povečevanja stopnje motorizacije in zniževanja deleža investicij v varstvo okolja, medtem ko ostaja obseg ekološko pomembnih območij, kot 
so območja Natura 2000 in površine gozda na prebivalca, večinoma nespremenjen. Ob tem je treba izpostaviti, da opisano ne velja za vse regije enako in da so nekatere vseeno uspele doseči izboljšanje tudi na področjih, kjer tega povprečje ne kaže.

$\mathrm{Na}$ podlagi preučitve posamičnih ekonomskih, socialnih in okoljskih kazalnikov trajnostnega razvoja smo lahko posebej identificirali tista področja, na katerih je relativni zaostanek regije za povprečjem največji in na katera bi bilo treba prioritetno usmeriti prizadevanja za doseganje ciljev bolj skladnega in trajnostnega razvoja v posameznih regijah (preglednica 4).

Preglednica 4: Področja, na katerih posamezne slovenske statistične regije izkazujejo z vidika trajnostnega razvoja izrazito neugodno stanje ali trende.

\begin{tabular}{|c|c|c|c|}
\hline $\begin{array}{l}\text { Statistična } \\
\text { regija }\end{array}$ & Področje & $\begin{array}{l}\text { Statistična } \\
\text { regija }\end{array}$ & Področje \\
\hline Pomurska & $\begin{array}{l}\text { - višina razpoložljivega } \\
\text { dohodka na prebivalca, } \\
\text { - upadanje števila prebivalcev, } \\
\text { - staranje prebivalstva*, } \\
\text { - stopnja brezposelnosti*, } \\
\text { - višje- in visokošolsko } \\
\text { izobraževanje - zastopanost } \\
\text { študentov, delež diplomantov, } \\
\text { - obseg intenzivno obdelanih } \\
\text { kmetijskih zemljišč, } \\
\text { - razširjenost ekološkega } \\
\text { kmetijstva, } \\
\text { - delež gospodinjstev, živečih v } \\
\text { onesnaženem okolju*, } \\
\text { - ražsirjenost daljinskega } \\
\text { ogrevanja gospodinjstev. }\end{array}$ & Podravska & $\begin{array}{l}\text { - višina razpoložljivega dohodka } \\
\text { na prebivalca, } \\
\text { - življenjsko pričakovanje - } \\
\text { starost ob smrti, } \\
\text { - stopnja tveganja socialne } \\
\text { izključenosti*, } \\
\text { - obseg gozdnatih površin, } \\
\text { - delež pozidanih površin*. }\end{array}$ \\
\hline Zasavska & $\begin{array}{l}\text { - višina bruto domačega } \\
\text { proizvoda, } \\
\text { - ustvarjena dodana vrednost } \\
\text { na prebivalca, } \\
\text { - investicije v osnovna sredstva, } \\
\text { - upadanje števila prebivalcev, } \\
\text { - stopnja tveganja socialne } \\
\text { izključenosti*, } \\
\text { - obseg stanovanjskih površin, } \\
\text { - raba računalnikov v } \\
\text { gospodinjstvih, } \\
\text { - delež gospodinjstev, živečih v } \\
\text { onesnaženem okolju, } \\
\text { - delež Natura } 2000 \text { območij. }^{*}\end{array}$ & Posavska & $\begin{array}{l}\text { - življenjsko pričakovanje - starost } \\
\text { ob smrti. }\end{array}$ \\
\hline
\end{tabular}




\begin{tabular}{|c|c|c|c|}
\hline $\begin{array}{l}\text { Statistična } \\
\text { regija }\end{array}$ & Področje & $\begin{array}{l}\text { Statistična } \\
\text { regija }\end{array}$ & Področje \\
\hline Savinjska & $\begin{array}{l}\text { - obseg stanovanjskih površin, } \\
\text { - delež gospodinjstev, živečih v } \\
\text { onesnaženem okolju*, } \\
\text { - delež Natura } 2000 \text { območij, } \\
\text { - delež prečiščene odpadne } \\
\text { vode. }\end{array}$ & Koroška & $\begin{array}{l}\text { - zaposlenost v storitvenih } \\
\text { dejavnostih, } \\
\text { - brezposelnost žensk }{ }^{*}, \\
\text { - življenjsko pričakovanje - starost } \\
\text { ob smrti, } \\
\text { - stopnja tveganja socialne } \\
\text { izključenosti*, } \\
\text { - živinorejska gostota*. }\end{array}$ \\
\hline $\begin{array}{l}\text { Primor- } \\
\text { sko-no- } \\
\text { tranjska }\end{array}$ & $\begin{array}{l}\text { - } \text { rast cestnega tovornega } \\
\text { prometa*, }^{*} \text { razširjenost daljinskega } \\
\text { ogrevanja gospodinjstev, } \\
\text { - } \text { stopnja motorizacije }^{\star} \text {. }\end{array}$ & $\begin{array}{l}\text { Obalno- } \\
\text { kraška }\end{array}$ & $\begin{array}{l}\text { - višje- in visokošolsko } \\
\text { izobraževanje - zastopanost } \\
\text { študentov, } \\
\text { - rast cestnega tovornega } \\
\text { prometa }^{*} \\
\text { - količine komunalnih odpadkov } \\
\text { - raba vode*. }\end{array}$ \\
\hline Goriška & $\begin{array}{l}\text { - raba vode }{ }^{\star}, \\
\text { - delež prečiščene odpadne } \\
\text { vode, } \\
\text { - stopnja motorizacije*. }\end{array}$ & Gorenjska & - živinorejska gostota*. \\
\hline $\begin{array}{l}\text { Jugov- } \\
\text { zhodna } \\
\text { Slovenija }\end{array}$ & $\begin{array}{l}\text { - zaposlenost v storitvenih } \\
\text { dejavnostih, } \\
\text { - brezposelnost slabše } \\
\text { izobraženih*, } \\
\text { - raba računalnikov v } \\
\text { gospodinjstvih. }\end{array}$ & $\begin{array}{l}\text { Osrednje- } \\
\text { slovenska }\end{array}$ & $\begin{array}{l}\text { - } \text { rast gostote poselitve*, } \\
\text { - obseg gozdnatih površin, } \\
\text { - delež pozidanih površin*, } \\
\text { - delež prečiščene odpadne vode. }\end{array}$ \\
\hline
\end{tabular}

Opomba: Pri posamezni regiii so izpostavljena le tista področja, na katerih je bil rezultat regije za več kot en standardni odklon slabši od povprečja regij (ti. ocena - - z vidika ugodnosti za trajnostni razvoj).

*Zviševanje vrednosti na tem področju pomeni oddaljevanje od trajnostnega razvoja.

\section{SKLEPI}

S preučitvijo izbranih kazalnikov smo ugotovili, da je bil razvojni napredek slovenskih statističnih regij po letu 2010 omejen le na posamezna socialno-ekonomska in okoljska področja ali razmerja. V splošnem ne moremo potrditi, da regije napredujejo $\mathrm{V}$ smeri ciljev trajnostnega in skladnejšega razvoja, saj preučeni kazalniki ne kažejo, da bi bil v zadnjem desetletju razvoj na ekonomskem, socialnem in okoljskem področju uravnotežen in da bi se regionalne razvojne razlike zmanjševale.

Čeprav se je BDP na prebivalca v državi in regijah zviševal, so se razlike med regijami postopoma nekoliko povečale. Podobno se ugotavlja tudi na podlagi izračunov IRO, katerega kazalniki sicer kažejo izboljšanje stanja, a hkrati tudi povečanje 
medregionalnih razlik (Pečar, 2020a). Na okoljskem področju ne prihaja do želenega zmanjšanja pritiskov na okolje, država in večina regij ob tem izkazujejo tudi ekološki deficit, ki opozarja na netrajnostni razvojni vzorec, po katerem se socialno-ekonomski razvoj odvija na račun degradacije okolja. Višji ekološki odtis in slabše rezultate na okoljskem področju trajnostnega razvoja imajo regije z zahodne polovice države (zlasti iz kohezijske regije Zahodna Slovenija), ki se sicer po socialnih in ekonomskih kazalnikih uvrščajo med najuspešnejše. Izjema je Primorsko-notranjska regija, saj je po razvojnih značilnostih bolj podobna regijam $z$ vzhodnega dela države.

Predvsem iz opazovanja trendov pri KTRR izhaja ugotovitev, da so se na ekonomskem področju razlike med regijami po letu 2010 nekoliko zmanjšale, medtem ko tega ni moč potrditi za socialno in okoljsko področje. Posebej pogosto so se rangi regij spreminjali pri okoljskih kazalnikih. Na eni strani večina socialnih in ekonomskih kazalnikov KTRR v zadnjem desetletju kaže na približevanje ciljem trajnostnega razvoja (npr. zmanjšanje brezposelnosti, izboljšanje izobrazbe, daljše življenjsko pričakovanje, boljše stanovanjske razmere, višji dohodki ipd.), na drugi strani pa večina okoljskih kazalnikov še vedno kaže na oddaljevanje od njih, kar se ujema tudi z ugotovitvami pri ekološkem odtisu in je povezano zlasti s povečevanjem rabe naravnih virov.

Pri interpretaciji rezultatov je treba upoštevati, da preučeni kazalniki pokrivajo le omejeno število značilnosti regionalnega razvoja in še vedno izkazujejo mnoge metodološke pomanjkljivosti. Za bolj konkretno spremljanje učinkovitosti regionalne politike bi bilo priporočljivo dogovoriti ciljne vrednosti za posamezne kazalnike in vzpostaviti celovit, poenoten sistem vrednotenja. Posamezne regije se soočajo z raznolikimi razvojnimi izzivi, zato bi si morala slovenska regionalna politika v prihodnje bolj ciljno prizadevati za preusmerjanje napredka v smer trajnostnega razvoja na tistih področjih, kjer se trenutno od njih odmikamo, poleg tega pa posebno pozornost namenjati področjem, na katerih posamezne regije najbolj zaostajajo, saj bo v nasprotnem primeru težko zmanjšati regionalne razvojne razlike in dosegati ustrezno raven blaginje v okviru nosilnih zmogljivosti okolja.

\section{Zahvala}

Raziskavo je finančno podprla Javna agencija za raziskovalno dejavnost Republike Slovenije v okviru raziskovalnega programa Trajnostni regionalni razvoj Slovenije (P6-0229).

\section{Literatura in viri}

Agenda 21. Programme of action for sustainable development, Rio declaration on environment and development. The United Nations conference on environment and development. 1992. Rio de Janeiro.

Cilji, usmeritve in instrumenti regionalne politike ter strateška izhodišča prostorskega razvoja za pripravo regionalnih razvojnih programov 2021-2027. 2019. Ljubljana: 
Ministrstvo za gospodarski razvoj in tehnologijo. URL: https://www.gov.si/teme/ spodbujanje-regionalnega-razvoja/ (citirano 20. 11.2021).

Cohesion policy 2021-2027. 2021. URL: https:/ec.europa.eu/regional_policy/ en/2021_2027/(citirano 20.11.2021).

Galli, A., Giampietro, M., Goldfinger, S., Lazarus, E., Lin, D., Saltelli, A., Wackernagel, M., Müller, F., 2016. Questioning the ecological footprint. Ecological Indicators, 69, str. 224-232. DOI: 10.1016/j.ecolind.2016.04.014.

Global Footprint Network. National footprint and biocapacity accounts, 2019 edition. 2019.

Global Footprint Network. Open data platform. 2021. URL: https://data.footprintnetwork.org/?_ga=2.172643811.159128246.1638108556-466437012.1613328104\#/ (citirano 20. 11. 2021).

Kalimeris, P., Bithas, K., Richardson, C., Nijkamp, P., 2020. Hidden linkages between resources and economy: A "Beyond-GDP" approach using alternative welfare indicators. Ecological Economics, 169. DOI: 10.1016/j.ecolecon.2019.106508.

Lin, D., Iha, K., Wambersie, L., Galli, A., Wackernagel, M., Bobovnik, N., Vintar Mally, K., Hanscom, L., 2020. Slovenia's ecological footprint. Technical report on the ecological footprint and biocapacity of 12 Slovenian regions. Updated October 2020. Oakland: Global Footprint Network.

O’Neill, D. W., Fanning, A. L., Lamb, W. F., Steinberger, J. K., 2018. A good life for all within planetary boundaries. Nature Sustainability, 1, str. 88-95. DOI: 10.1038/ s41893-018-0021-4.

Operativni načrt o sodelovanju ministrstev pri pripravi regionalnih razvojnih programov za obdobje 2021-2027. 2019. Ljubljana: Ministrstvo za gospodarski razvoj in tehnologijo. URL: https://www.gov.si/teme/spodbujanje-regionalnega-razvoja/ (citirano 20. 11.2021).

Pečar, J., 2018. Indeks razvojne ogroženosti regij 2014-2020, metodologija izračuna. Ljubljana: Urad RS za makroekonomske analize in razvoj.

Pečar, J., 2020a. Indeks razvojne ogroženosti regij 2019. Ljubljana: Urad RS za makroekonomske analize in razvoj.

Pečar, J., 2020b. Cilji regionalne politike Slovenije v obdobju 2021-2027. Ljubljana: Urad RS za makroekonomske analize in razvoj.

Pravilnik o razvrstitvi razvojnih regij po stopnji razvitosti za programsko obdobje 2021-2027. 2021. Ljubljana: Uradni list Republike Slovenije.

Priprava Strategije prostorskega razvoja Slovenije. 2021. URL: https://www.gov.si/ zbirke/projekti-in-programi/strategija-prostorskega-razvoja-slovenije/ (citirano 20. 11.2021).

Renewed EU sustainable development strategy. 2006. Brussels: Council of the European Union.

Strategija razvoja Slovenije 2030. 2017. Ljubljana: Služba vlade za razvoj in evropsko kohezijsko politiko. 
SURS [Statistični urad Republike Slovenije], 2021. Podatkovna baza SiStat. URL: https://pxweb.stat.si/SiStat/sl (citirano 20. 11.2021).

The European green deal. 2019. Brussels: European Commission.

Transforming our world: the 2030 agenda for sustainable development. 2015. United Nations.

van den Bergh J. C. J. M., The GDP paradox. Journal of Economic Psychology, 30, str. 117-135. DOI: 10.1016/j.joep.2008.12.001.

Vintar, K., 2003. Okoljevarstveni vidiki sonaravnega regionalnega razvoja Slovenije. Magistrsko delo. Ljubljana: Oddelek za geografijo Filozofske fakultete Univerze v Ljubljani.

Vintar Mally, K., 2009. (Ne)sonaravnost razvoja slovenskih regij. V: Nared, J., Perko, D. (ur.). Razvojni izzivi Slovenije. Ljubljana: Geografski inštitut Antona Melika ZRC SAZU, str. 263-270.

Vintar Mally, K., 2018. Regional differences in Slovenia from the viewpoint of achieving Europe's sustainable development. Acta Geographica Slovenica, 58, 2, str. 31-46. DOI: 10.3986/AGS.3309.

Vintar Mally, K., 2021. Trends in regional development in Slovenia in the light of the goals of sustainable development. European Journal of Geography, 12, 2, str. 36-51. DOI: 10.48088/ejg.k.mal.12.2.36.51.

Ward, J. D., Sutton, P. C., Werner, A. D., Costanza, R., Mohr, S. H., Simmons, C. T., 2016. Is decoupling GDP growth from environmental impact possible? PLoS ONE: 11, 10. DOI: 10.1371/journal.pone.0164733.

Wiedmann, T., Barrett, J., 2010. A review of the ecological footprint indicator Perceptions and methods. Sustainability, 2, 6, str. 1645-1693. DOI: https://doi. org/10.3390/su2061645.

Zakon o spodbujanju skladnega regionalnega razvoja (ZSRR-2) - Promotion of balanced regional development act (ZSRR-2). 2011. Ljubljana: Uradni list Republike Slovenije. 